\title{
The effect of nutrient supply and light intensity on tannins and mycorrhizal colonisation in Dutch heathland ecosystems
}

\author{
Jantineke D. Hofland-Zijlstra $\cdot$ Frank Berendse
}

Received: 28 July 2006/Accepted: 14 November 2008/Published online: 2 December 2008

(C) The Author(s) 2008. This article is published with open access at Springerlink.com

\begin{abstract}
Increased atmospheric nitrogen deposition has shifted plant dominance from ericaceous plants to grass species. To elucidate the reduced competitiveness of heather, we tested the hypothesis that additions of nitrogen reduce the concentrations of phenolics and condensed tannins in ericaceous leaves and retard mycorrhizal colonisation in ericaceous plants. We also tested the negative effects of reduced light intensity on carbon-based secondary compounds and mycorrhizal colonisation in ericaceous plants. (2) We performed a field inventory at three heathland sites in the Netherlands varying in nutrient supply and light intensity. Leaves of ericaceous plants and grasses were collected and analysed for concentrations of tannins, phenolics and nutrients. Similarly, we took root samples to record mycorrhizal colonisation and soil samples to measure the soil mineralisation. In addition, we conducted two-factorial experiments with Calluna vulgaris plants, in which we varied fertiliser and shade levels under greenhouse and field conditions. (3) The field inventory revealed that nitrogen addition and shading both negatively affected the concentration of total phenolics. The total phenolics and condensed tannin concentrations were positively correlated $(P<0.001)$, but in the field experiment, the condensed
\end{abstract}

J. D. Hofland-Zijlstra $(\bowtie) \cdot$ F. Berendse

Nature Conservation and Plant Ecology Group, Wageningen University, Droevendaalsesteeg 3a, PO Box 47, 6700 AA Wageningen, The Netherlands e-mail: jantineke.hofland-zijlstra@wur.nl tannins were not significantly affected by the treatments. Our results provide the first evidence that the carbon nutrient balance can be used to predict the amount of total phenolics in the dwarf shrub C. vulgaris. (4) In the field experiments, shading of plants resulted in significantly less mycorrhizal colonisation. Only in the greenhouse experiment did addition of nitrogen negatively affect mycorrhizal colonisation. (5) Our results imply that increased atmospheric nitrogen deposition can depress the tannin concentrations in ericaceous plants and the mycorrhizal colonisation in roots, thereby reducing the plants' competitiveness with respect to grasses. Additionally, if ericaceous plants are shaded by grasses that have become dominant due to increased nitrogen supply, these effects will be intensified and competitive replacement will be accelerated.

Keywords Calluna vulgaris . Carbon-nutrient balance - Dominant grasses . Ericaceae Ericoid mycorrhiza $\cdot$ Nitrogen deposition

\section{Introduction}

In The Netherlands, increased atmospheric nitrogen deposition has shifted plant dominance in heathlands from ericaceous plants towards grass species (Berendse and Aerts 1984; Aerts 1993; Berendse et al. 1994). It is estimated that around $35 \%$ of the 
heathland area has become grass-dominated (Bobbink et al.1998). The increased dominance of grasses has been attributed to their higher growth rate potential than that of dwarf shrubs (Berendse and Elberse 1990). Furthermore, outbreaks of heather beetle in nitrogen-fertilised vegetation have also strongly accelerated the expansion of grasses (Heil and Diemont 1983; Bobbink and Heil 1993; Power et al. 1998). Other factors (e.g. drought- and frost resistance of dwarf shrubs) can also be affected by changes in nitrogen deposition (Power et al. 1998).

An alternative hypothesis, proposed by Northup et al. $(1995,1998)$ suggested that the dominance of plant species in nutrient-poor ecosystems is the outcome of the production of high levels of carbonbased secondary compounds, e.g. tannins. Mineralisation has traditionally been considered to be the critical factor in nitrogen cycling, the decisive factor in nutrient-poor ecosystems (Chapin 1995; Northup et al. 1995). However, evidence is increasing that the production of large amounts of tannins and the concomitant utilisation of organic nitrogen enables plants in nutrient-poor ecosystems to short-cut the nitrogen cycle, so reducing their dependence on soil nitrogen mineralisation (Bradley et al. 2000; Fierer et al. 2001, Schimel et al. 1996, 1998). So, within these ecosystems plant species, which are able to use organic nitrogen, are expected to have a competitive advantage over plants which are not able to use these nitrogen sources.

Tannins can be subdivided into the hydrolysable tannins (sugar molecules esterified by a number of gallic acid moieties) and the condensed tannins, also referred to as proanthocyanidins (polymers of flavan3-ols) (Harborne 1997). Both types of tannins can affect nutrient availability in the soil. They interact with proteins during the decomposition of litter material (Schimel et al. 1996; Fierer et al. 2001; Haslam 1998). Tannin-protein complexes are difficult to mineralise, and subsequently, they determine the proportions of nitrogen released in dissolved organic and inorganic forms $\left(\mathrm{NH}_{4}{ }^{+}, \mathrm{NO}_{3}{ }^{-}\right)$(Handley 1961; Northup et al. 1995)

Ericaceous plants can use organic nitrogen more efficiently due to symbiosis with ericoid mycorrhizal fungi (Bending and Read 1997). Via the exudative enzymes, these fungi are able to solubilise tanninprotein complexes (Bending and Read 1997). Sokolovski et al. (2002) showed that Calluna vulgaris (L.)
Hull roots are able to use more organic nitrogen when colonised with these fungal symbionts. Therefore, at low mineralisation rates, ericaceous plants are thought to outcompete plant species that form arbuscular mycorrhiza, or non-mycorrhizal plants unable or less able to absorb organic nitrogen (Northup et al. 1998; Read et al. 2004).

Additions of nitrogen can have negative effects on the carbon-based secondary compounds in ericaceous leaves (Bryant et al. 1983). According to the carbon nutrient balance (CNB) hypothesis (Bryant et al. 1983), an increase in nitrogen concentration-as a result of increased nitrogen deposition-would reduce the production of carbon-based secondary compounds. In this case, the available carbon is invested in growth rather than in defence. It is well established that nitrogen addition increases nitrogen concentrations in heather, C. vulgaris (Berdowski and Siepel 1988; Iason et al. 1993; Duncan et al. 1994; Hartley et al. 1995; Carrol et al. 1999; Gordon et al. 1999) and other ericaceous plants (Mallik 1996; Prescott et al. 1993; Nordin et al. 1998). However, the expected decrease in total phenolics or condensed tannin levels due to solely nitrogen additions has not yet been empirically shown either in the greenhouse or in the field (Iason and Hester 1993; Iason et al. 1993; Hartley et al. 1995; Kerslake et al. 1998; Bradley et al. 2000; Alonso et al. 2001; Hansen et al. 2006). In contrast, Hansen et al. (2006) recently showed that a combination of nitrogen addition with increased air temperature seems to induce a positive response of condensed tannins in one year old leaves of Vaccinium vitis-ideae (L.) and Cassiope tetragona (L.) D. Don.

Increased levels of atmospheric nitrogen can also lead to decreases in ericoid mycorrhizal colonisation of ericaceous roots. With increased inorganic nitrogen supply, one would expect that the plant invests less carbon to symbiosis with root-associated fungi, and so ericaceous dwarf shrubs would hardly be able to compete with grasses. Two greenhouse experiments have shown that ammonium addition can negatively affect the extent of ericoid mycorrhizal colonisation in C. vulgaris roots (Mickel et al. 1991; Yesmin et al. 1996). However, there is no indication from field experiments that adding nitrogen reduces mycorrhizal colonisation (Lee et al. 1992; Caporn et al. 1995; Johannson 2000).

Light intensity can also influence the amounts of carbon-based secondary compounds and mycorrhizal 
colonisation in ericaceous plants. In the context of shrub-grass dynamics, this can be important as when ericaceous plants become shaded by grasses that have become dominant due to increased nitrogen supplies competition replacement can be accelerated through these effects. Conflicting results on the effects of shading on the amounts of carbon-based secondary compounds have been published. Iason and Hester (1993) showed in a field experiment that shading reduced the concentration of total phenolics in C. vulgaris. In contrast, Hartley et al. (1995) found no effects of shading on the concentration of total phenolics and condensed tannins in C. vulgaris plants. Whereas, Hansen et al. (2006) even found a positive response of shading on the concentration of condensed tannins in $V$. vitis-idaea and C. tetragona. In non-ericaceous plants, shading usually reduces the levels of carbon-based secondary chemicals (Hartley et al. 1997; Henriksson et al. 2003, Ruohomäki et al. 1996; Iason et al. 1996). In plants with ectomycorrhizal fungal symbionts, shade effects on the amount of colonisation or amounts of structures are ranging from no effect (Brearly et al. 2007; Dehlin et al. 2004) to decreased colonisation rates (Becker 1983; Ingleby et al. 1998) or even increased colonisation rates (Prajadinata and Santoso 1993; Be'reau et al. 2000). As these ectomycorrhizal fungi produce a Hartig net around the roots, we assume that they show a different response to shading compared to ericoid mycorrhizal fungi, which only proliferate within the epidermal cells of roots. A field study in a subarctic birch forest understorey with Empetrum, Vaccinium and Andromeda species suggests that there is a positive correlation between photosynthetic activity and ergosterol concentration in ericoid roots (Olsrud et al. 2004). However, the same authors also showed that ergosterol content in ericoid mycorrhizal is not correlated with ericoid mycorrhizal colonisation, but is only indicative for the presence of dark septate endophytes (Olsrud et al. 2007). So far, the effect of shading on mycorrhizal colonisation in ericaceous plants is still unclear. We, therefore, decided to test the hypothesis that shaded plants will invest less in mycorrhizal symbiosis and mycorrhizal colonisation will be reduced.

The relation between phenolic levels in plant material and mycorrhizal colonisation has been hypothesized, but it was never thoroughly examined
(Hättenschwiler and Vitousek 2000; Northup et al. 1998). In this research, we asked which abiotic factors (nitrogen and light) would significantly influence the levels of both phenolic compounds and of mycorrhizal colonisation. To circumvent the shortcoming of one particular research method, we combined field observations with greenhouse and field experiments. Initially, we carried out a field inventory on several heathland plants, to study the natural variation of phenolics, condensed tannins and mycorrhizal colonisation in the field. We selected two heathland sites and two Quercus-Vaccinium forest sites in the centre and north of The Netherlands. At the heathland sites, we selected two areas, which differed in soil nitrogen supply (soil subjected to recent sod removal vs. soil with a thick organic layer) and at the Quercus sites, we selected plots, which varied in natural light intensity (shaded vs. nonshaded communities). Additionally, at one of the sites we choose an area where we collected four ericaceous plant species and two dominant grass species, to analyse the interspecific variation in phenolic and condensed tannin levels. Subsequently, we conducted fertiliser experiments, with $C$. vulgaris in the greenhouse and under field conditions. In these experiments, we also applied shading to test the negative feedback of reduced light intensity on phenolic compounds and mycorrhizal colonisation.

\section{Methods}

Field inventory

\section{Field sites and selected species}

The field locations were selected at three sites in The Netherlands: in the north, Dwingelderveld National Park (A, $52^{\circ} 47^{\prime} \mathrm{N}, 6^{\circ} 25^{\prime} \mathrm{E}$ ); in the centre, De Hoge Veluwe National Park (B, $\left.52^{\circ} 4^{\prime} \mathrm{N}, 5^{\circ} 50^{\prime} \mathrm{E}\right)$ and Hoog Buurlo (C, $\left.52^{\circ} 10^{\prime} \mathrm{N}, 5^{\circ} 54^{\prime} \mathrm{E}\right)$. Table 1 shows the collected plant species and relevant soil data for each site. To compare variation in plant chemistry as affected by soil nutrient supply, we selected two dwarf shrub vegetation sites (A and B) with $C$. vulgaris and Deschampsia flexuosa (L.) Trin. Plots in recently turf-stripped sites were chosen adjacent to older heathland sites. At the stripped plots the turf layer had been removed up to four years prior to 
Table 1 Field inventory overview of the investigated site pairs contrasting with respect to soil nutrients (A) or light intensity (B), showing growth conditions, the plant species collected at each site, and related soil nutrient factors $(\mathrm{mean} \pm \mathrm{SE}$, d.f. $=4$ )

\begin{tabular}{|c|c|c|c|c|c|c|c|}
\hline \multicolumn{5}{|l|}{ A: Soil nutrients } & \multicolumn{2}{|l|}{ Sod removed } & \multirow[t]{2}{*}{ Interaction } \\
\hline Site & A & A & B & B & & & \\
\hline Growth conditions & Sod removal (N-) & $\begin{array}{c}\text { Thick organic } \\
\text { layer }(\mathrm{N}+)\end{array}$ & Sod removal $(\mathrm{N}-)$ & $\begin{array}{c}\text { Thick organic } \\
\text { layer }(\mathrm{N}+)\end{array}$ & & & \\
\hline Plant species & $\mathrm{Cv}$ & $\mathrm{Cv}$ & $\mathrm{Cv}$ & $\mathrm{Cv}$ & & & \\
\hline $\begin{array}{c}N \text { mineralisation } \\
\left(\mathrm{g} \mathrm{N} / \mathrm{m}^{2} / \text { year }\right)\end{array}$ & $2.5(2.1)$ & $4.6(3.1)$ & $0.8(0.2)$ & $12.0(4.2)$ & $* * *$ & $*$ & $* *$ \\
\hline C:N soil & 34.5 (1.9) & $28.7(0.6)$ & $24.6(0.4)$ & $25.9(0.6)$ & NS & $* * *$ & $* *$ \\
\hline $\mathrm{pH}-\mathrm{KCl}$ & $3.1(0.1)$ & $2.9(0.0)$ & $3.4(0.1)$ & $2.9(0.0)$ & $* * *$ & NS & NS \\
\hline Org. matter (\%) & $0.10(0.0)$ & $0.13(0.02)$ & $0.06(0.0)$ & $0.12(0.01)$ & $*$ & NS & NS \\
\hline B: Light intensity & & & & & Shade & Site & Interaction \\
\hline Site & A & A & $\mathrm{C}$ & $\mathrm{C}$ & & & \\
\hline Growth conditions & No shade $(\mathrm{S}-)$ & Shade $(\mathrm{S}+)$ & No shade $(\mathrm{S}-)$ & Shade $(\mathrm{S}+)$ & & & \\
\hline Plant species & Vvi & Vvi & $\mathrm{Vm}$ & $\mathrm{Vm}$ & & & \\
\hline $\begin{array}{c}\mathrm{N} \text { mineralisation } \\
\left(\mathrm{g} \mathrm{N} / \mathrm{m}^{2} / \text { year }\right)\end{array}$ & $5.2(7.2)$ & $3.4(4.6)$ & $10.7(6.3)$ & $15.9(6.0)$ & NS & $* *$ & NS \\
\hline $\mathrm{C}: \mathrm{N}$ soil & $25.9(1.5)$ & $24.3(0.7)$ & $25.6(0.3)$ & $20.1(0.3)$ & $* * *$ & $*$ & $*$ \\
\hline $\mathrm{pH}-\mathrm{KCl}$ & $2.8(0.2)$ & $2.9(0.1)$ & $2.8(0.0)$ & $2.9(0.0)$ & NS & NS & NS \\
\hline Org. matter $(\%)$ & $0.17(0.02)$ & $0.11(0.04)$ & $0.16(0.01)$ & $0.08(0.01)$ & $* * *$ & NS & NS \\
\hline
\end{tabular}

Sites: A = Dwingelderveld National Park; B = De Hoge Veluwe National Park; C = Hoog Buurlo. Plant species: Cv = Calluna vulgaris; $\mathrm{Vvi}=$ Vaccinium vitis-idaea $; \mathrm{Vm}=$ V. myrtillus. Significance levels for the main effects and the interaction between them are given

$* P<0.05 ; * * P<0.01 ; * * * P<0.001$

$\mathrm{NS}=$ non-significant

plant collection. The groundwater levels of the sites were similar. The effects of light intensity on Vaccinium and Deschampsia were investigated by comparing the natural occurring variation in shaded (50\% incident light) and non-shaded plots in Quercus robur L. woodlands on sites at Dwingelderveld National Park and Hoog Buurlo. The Quercus robur L. woodlands consisted of a herbaceous layer dominated by the ericaceous dwarf shrubs Vaccinium vitis-idaea L. (A) or Vaccinium myrtillus L. (C) and the grass D. flexuosa. We preferred to select the Quercus woodlands as these are one of the few available places in The Netherlands where we could find shaded ericaceous plants. The additional site at Hoog Buurlo was a mixed heathland with $C$. vulgaris, Erica tetralix L., V. myrtillus, V. vitis-idaea L., Molinia caerulea (L.) Moench and D. flexuosa. The field sites were roughly $25 \times 50 \mathrm{~m}$. Within each site, five plots of $1 \mathrm{~m}^{2}$ were chosen 10-25 m apart.

\section{Leaf measurements}

Plant material was collected on 5th and 6th June and 7th and 8th September 2000. Only the first year growth of green leaves was sampled. For proper handling of the leaf material prior to analyses, we followed the guidelines described in Waterman and Mole (1994). The leaf material was kept cool and brought to the laboratory where it was frozen immediately $\left(-18^{\circ} \mathrm{C}\right)$ until handled for analyses. Leaves were dried for two days at $38^{\circ} \mathrm{C}$. The leaves were separated from stems and flowers by sieving ( $2 \mathrm{~mm}$ ) before grinding. For extraction $20 \mathrm{ml}$ of $50 \%$ (v/v) methanol was added to $0.19 \mathrm{~g}$ dry leaf material. The mixture was covered and placed in a water bath $\left(75^{\circ} \mathrm{C}\right)$ for $1 \mathrm{~h}$. The sample was then filtered through a glass filter and the extract adjusted to $50 \mathrm{ml}$ with $50 \%(\mathrm{v} / \mathrm{v})$ methanol. Total phenolics were determined following the Folin-Ciocalteu method (Waterman and Mole 1994). Condensed tannins were 
analysed following the butanol- $\mathrm{HCl}$ method of Porter et al. (1986). All analyses were performed in duplicate. Given the problems and complexities of applying an appropriate standard for the proanthocyanidin method (Waterman and Mole 1994), the data are presented as final absorbance at $550 \mathrm{~nm}$. Another portion of dried leaves $\left(70^{\circ} \mathrm{C}\right)$ was pulverised and $\mathrm{C}$ and $\mathrm{N}$ concentrations were measured using an elemental analyser (Fisons Instruments, EA 1108).

\section{Soil measurements}

Soil cores (10 cm deep, $5 \mathrm{~cm}$ diameter) were taken on 5th and 6th June 2000 and stored at $4^{\circ} \mathrm{C}$ overnight. After removing any coarse roots and stones, the extractable $\mathrm{NH}_{4}-\mathrm{N}$ and $\mathrm{NO}_{3}-\mathrm{N}$ were determined in $10 \mathrm{~g}$ fresh soil extracted in $25 \mathrm{ml} 1 \mathrm{M} \mathrm{KCl}$. The extracts were filtered through filter paper (Schleicher and Schüll no. $589^{3}$ ). Concentrations of the extractable ions in the soil were calculated from the concentrations in the extract using the soil water content. The soil $\mathrm{pH}$ was also measured in the same soil extract. To estimate the net mineralisation rate, a subsample of $10 \mathrm{~g}$ soil was incubated for 6 weeks at $20^{\circ} \mathrm{C}$ and then the extractable $\mathrm{NH}_{4}-\mathrm{N}$ and $\mathrm{NO}_{3}-\mathrm{N}$ were measured. Net mineralisation rates were calculated from the difference between the amount of $\mathrm{NH}_{4}{ }^{+}$and $\mathrm{NO}_{3}{ }^{-}$before and after incubation. To measure the soil water content a subsample of $5 \mathrm{~g}$ soil was dried $\left(105^{\circ} \mathrm{C}\right)$ overnight. Organic matter content was determined after combustion at $550^{\circ} \mathrm{C}$. The $\mathrm{C}$ and $\mathrm{N}$ concentrations were measured using an elemental analyser (Fisons Instruments, EA 1108).

\section{Collection of plant roots and mycorrhizal analyses}

For each species, roots of one individual plant were collected in each plot on 7th and 8th September 2000 with a soil auger of $20 \mathrm{~cm}(10 \mathrm{~cm}$ diameter $)$. The roots were kept moist in a plastic bag $(25 \times 10 \mathrm{~cm})$. The soil was removed by washing the roots over a $2 \mathrm{~mm}$ sieve. In the laboratory, roots were further cleaned from organic material with forceps, and stored in 50\% ethanol. They were then stained in $0.2 \%$ solution of trypan blue in lactic acid:glycerol:water (3.25:3:4 by vol.) and transferred to a storage solution of lactic acid:glycerol:water (1:2:1 by vol.). From each root system of an individual plant, 30 healthy root tips were then randomly selected, mounted on a microscopic slide and, using a light microscope, were examined at $40 \times$ magnification for the presence of ericoid mycorrhizal structures in ericaceous roots and for arbuscular mycorrhizal structures in grass roots. Ericoid mycorrhizal structures are most abundantly present in root tips and can be recognized by hyphal coils in epidermal root cells (Read 1996). AMF colonisation was recognized by the presence of vesicles and arbuscules connected to broad, aseptate hyphae. Colonisation of epidermal cells in each root tip was estimated as percentage of colonized cells in the superficial cell layers in $1 \mathrm{~cm}$ root.

\section{Greenhouse experiment}

From May 2001 to March 2002, we conducted a twofactorial experiment with shading and fertilisation in a greenhouse with controlled climatic conditions (light/dark: 14/10 h., light intensity $50 \mathrm{~W} \mathrm{~m}^{-2}$, temperature day/night: $20^{\circ} \mathrm{C} / 15^{\circ} \mathrm{C}, 70 \%$ R.H.). The treatments were: no shade or fertiliser $(\mathrm{S}-\mathrm{F}-)$, fertiliser $(\mathrm{S}-\mathrm{F}+)$, shade $(\mathrm{S}+\mathrm{F}-)$, shade and fertiliser $(\mathrm{S}+\mathrm{F}+)$. Each treatment was replicated five times. Twenty plastic pots $(14 \mathrm{~cm}$ diam $)$ were filled with $2.5 \mathrm{~kg}$ sand (sand mixed with organic-rich soil, 5:1, $\mathrm{v} / \mathrm{v})$. We added one part organic-rich soil to provide the control treatments with a basic level of nutrients. C. vulgaris seedlings $(\sim 2.5 \mathrm{~cm}$ tall $)$ were collected from the De Hoge Veluwe National Park and placed three in each pot. Given the results of the field study, we assumed that all roots from the collected $C$. vulgaris seedlings were colonised by mycorrhizal fungi. The shade treatment involved excluding $50 \%$ of incident light using shade netting around each individual pot. The pots were spaced widely to avoid the shade netting constructions shading other plants. Fertilised plants received amounts equivalent to $75 \mathrm{~kg} \mathrm{~N}, 25 \mathrm{~kg} \mathrm{P}$ and $50 \mathrm{~kg} \mathrm{~K} \mathrm{ha}^{-1}$ year $^{-1}$. The fertiliser was applied in June and August. In this experiment, we chose a compound fertiliser, to prevent phosphate limitations. The pots were placed randomly. The plants were watered regularly to keep the soil moisture at $60 \%$ of water saturation; for this purpose, the pots were weighed twice per week. After 12 months the above-ground plant parts were clipped off at soil level and dried at $38^{\circ} \mathrm{C}$, to measure the dry weight. The roots were gently removed from the soil, then washed to remove any adhering soil and also 
dried at $38^{\circ} \mathrm{C}$. Total phenolics, condensed tannins, nitrogen and carbon content and mycorrhizal colonisation were measured as described in the previous section. The amounts of inorganic nitrogen and $\mathrm{pH}$ $\mathrm{KCl}$ of the soil were determined.

\section{Field experiment}

At a site in De Hoge Veluwe National Park a field experiment was carried out from September 2001 to March 2003. The field site $(50 \times 60 \mathrm{~m})$ was a heathland dominated by $C$. vulgaris. Other plant species were E. tetralix, M. caerulea and D. flexuosa. The field treatments were similar to the treatments in the greenhouse experiment. Each treatment was replicated at five sites in this area, following a randomised block design. Within a site, individual plots of $1 \mathrm{~m}^{2}$ were chosen 5-10 $\mathrm{m}$ apart and the sites were spaced at $40-50 \mathrm{~m}$. Each plot was fenced with fine-meshed wire to exclude large herbivores. To reduce the light by $50 \%$ in the shade treatments, shade nets were put around and above the enclosures (1 $\mathrm{m}$ height). The fertilised plots received $50 \mathrm{~kg} \mathrm{~N} \mathrm{ha}^{-1}$ year $^{-1}\left(\mathrm{NH}_{4} \mathrm{NO}_{3}\right)$ in a single treatment. Initial amounts of soil nitrogen were measured before the enclosures were erected and again at harvest. Inorganic nitrogen was measured as described earlier and the total dissolved nitrogen $(\mathrm{DON}+$ inorganic $\mathrm{N})$ was determined conductimetrically after persulfate oxidation of the extract ( $\mathrm{Yu}$ et al. 1993). DON was calculated by subtracting inorganic nitrogen from the total dissolved nitrogen. At the end of the experimental period, the first year's growth of green leaves is harvested. Per plot, we collected one root sample. Shoots and roots were analysed as described for the field inventory.

\section{Statistical analyses}

\section{Field inventory}

The effects of sod removal or light intensity on soil chemistry parameters was analysed using ANOVA with sod removal and site, or light intensity and site as the respective fixed factors $(P<0.05)$. The effects of sod removal on plant characteristics were analysed using ANOVA with sod removal and site as the fixed factors $(P<0.05)$. The effects of light intensity on plant characteristics was analysed by ANOVA with shade and plant species as the fixed factors $(P<0.05)$. If the assumption of heterogeneity of variance was violated, the data were log-transformed. To compare total phenolic levels between plants under different treatments at one site, one-way ANOVA was carried out followed by the Tukey post hoc test $(P<0.05)$.

\section{Field and greenhouse experiment}

The results of the greenhouse and field experiments were analysed using two-way ANOVA with shade and fertiliser as fixed factors $(P<0.05)$.

\section{Results}

\section{Field inventory}

On sites where the turf layer had recently been stripped, the net mineralisation of the soil was lower than on older heathland sites with thicker organic layers (Table 1). No differences in net mineralisation were found between the shaded and non-shaded sites. The sites with V. myrtillus showed higher mineralisation rates compared to the sites with $V$. vitis-idaea (Table 1). The concentration of total phenolics in the plant ranged from 50-437 mg tannic acid equivalents/g dry weight (Fig. 1a-c). Differences between the amounts of phenolics were related to plant species, growth conditions and site (Table 2). Ericaceous leaves contained larger amounts of total phenolics than the grasses (Fig. 1c, $P<0.001$ ). There was also considerable variation among the ericaceous species. At the species-rich site at Hoog Buurlo, V. myrtillus leaves contained the highest amounts of total phenolics, V. vitis-idaea and C. vulgaris were intermediate, while levels were lowest in E. tetralix (Fig. 1c, $P<0.05$ ). Soil nutrient supply significantly decreased the concentration of total phenolics and condensed tannins. C. vulgaris showed higher levels of total phenolics and condensed tannins in leaves when grown on humus-poor soils compared to humus-rich soils (Fig. 1a; Table 2). Shade also decreased the levels of phenolics and tannins (Table 2). Plants growing under shaded conditions produced remarkably less total phenolics and condensed tannins, not only in the ericaceous plants, but also in the grass D. flexuosa (Fig. 1b, e; Table 2). 

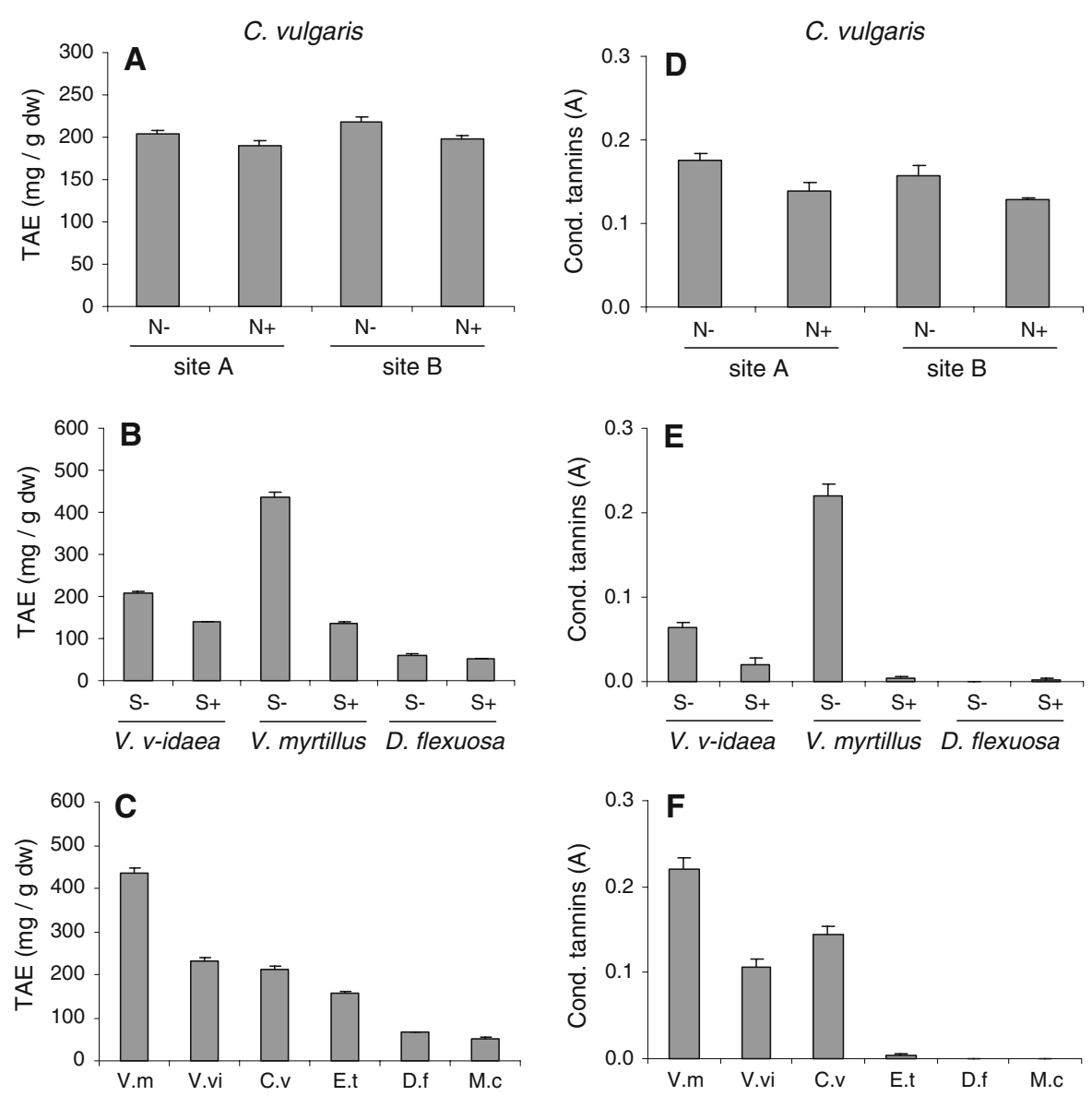

Fig. 1 Results of the field inventory. Mean values of total phenolics (TAE $=$ tannic acid eq. $\mathrm{mg} / \mathrm{g} \mathrm{dw}$ ) (a)-(c) and condensed tannins (absorption value) (d)-(f) in ericaceous plants and grasses at contrasting growth conditions and sites. a and d Nutrient contrasts: $\mathrm{N}-=$ sod removed, $\mathrm{N}+=$ thick organic layer. Site $\mathrm{A}=$ Dwingelderveld National Park; site B = De Hoge Veluwe National Park. b and e Light intensity

There was a strong positive relationship between the amount of total phenolics and the amount of condensed tannins (Table 2, $r^{2}=0.72, P<0.001$ ), especially in the ericaceous species. The nitrogen concentration and $\mathrm{C}: \mathrm{N}$ ratio in plant leaves depended on plant species, growth condition and site (Table 2). The level of mycorrhizal colonisation depended on growth conditions and plant species (Fig. 2; Table 2). We did not find a significant effect of sod removal on the level of mycorrhizal colonisation at the C. vulgaris sites. In contrast, shading had a clear negative effect on mycorrizal colonisation in roots of Vaccinium plants. Shading also reduced mycorrhizal

contrasts within Vaccinium vitis-idaea (site A), V. myrtillus (site C) and D. flexuosa (site C): $\mathrm{S}+=$ shaded, $\mathrm{S}-=$ nonshaded. $\mathbf{c}$ and $\mathbf{f}$ Non-shaded site at Hoog Buurlo (site C) with four ericaceous plants and two dominant grasses: C.v, Calluna vulgaris; E.t, Erica tetralix; D.f, Deschampsia flexuosa; M.c, Molinia caerulea; V.vi, Vaccinium vitis-idaea; V.m, V. myrtillus. Data are $\pm \operatorname{SE}(n=5)$

colonisation in grass roots, but to a lesser extent compared to the ericaceous plants.

\section{Greenhouse experiment}

Total biomass of the $C$. vulgaris plants was affected by both shade and fertiliser treatments (Table 3). With nitrogen fertilisation, the plants produced more shoots and roots. Shading induced a reduction of the root biomass: the related shoot:root ratios were increased by more than $100 \%$. Flower production was increased by fertilisation and decreased by shade. Surprisingly, the amount of total phenolics increased 
Table 2 Analysis of variation in plant chemistry: amount of total polyphenols, condensed tannins, mycorrhizal colonisation, concentration of nitrogen, concentration of carbon, and leaf $\mathrm{C}: \mathrm{N}$ ratio

\begin{tabular}{|c|c|c|c|c|c|c|}
\hline & Total phenolics & Condensed tannins & Mycorrhizal colonisation & $\mathrm{C}(\%)$ & $\mathrm{N}(\%)$ & $\mathrm{C}: \mathrm{N}$ ratio \\
\hline \multicolumn{7}{|l|}{ Soil nutrients } \\
\hline Sod removal & $14.0 * *$ & $16.6 * * *$ & 0.0 & 0.2 & $230.8 * * *$ & $314.2 * * *$ \\
\hline Site & $7.2^{*}$ & 2.8 & 1.9 & $16.6^{* * *}$ & $31.9 * * *$ & $23.2 * * *$ \\
\hline Interaction & 0.6 & 0.2 & $12.9 * *$ & 0.5 & 2.5 & 0.0 \\
\hline \multicolumn{7}{|l|}{ Light intensity } \\
\hline Shading & $980.3 * * *$ & $217.5 * * *$ & $16.1 * * *$ & 3.8 & $211.7 * * *$ & $225.8 * * *$ \\
\hline Plant species & $1016.1 * * *$ & $123.5 * * *$ & $8.6 * *$ & $80.8 * * *$ & $153.9 * * *$ & $300.2 * * *$ \\
\hline Interaction & $461.1 * * *$ & $129.5 * * *$ & 2.1 & $6.5 * *$ & $9.8 * * *$ & 0.1 \\
\hline
\end{tabular}

F values and significance levels for the main effects of the factors sod removal, site, shading and plant species, and the interaction between them are given

$* P<0.05 ; * * P<0.01 ; * * * P<0.001$
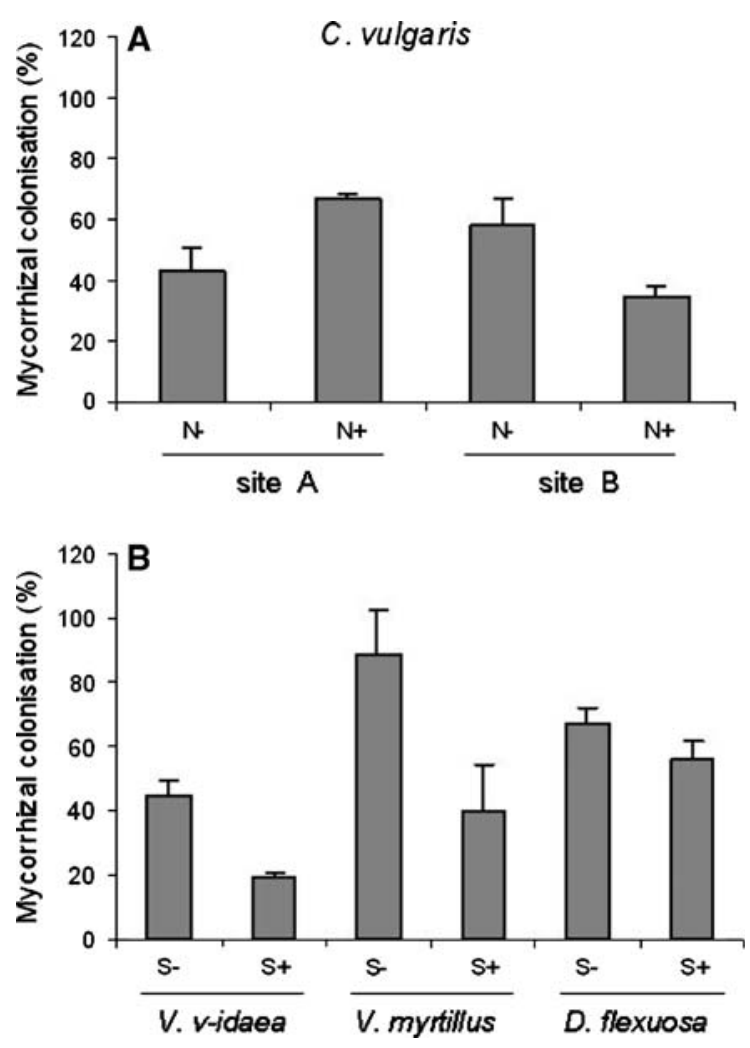

Fig. 2 Mycorrhizal colonisation (\%) in roots of Calluna vulgaris, Vaccinium vitis-idaea, V. myrtillus and Deschampsia flexuosa under contrasting growth conditions. a Nutrient contrasts: $\mathrm{N}-=$ sod removed, $\mathrm{N}+=$ thick organic layer. Site $\mathrm{A}=$ Dwingelderveld National Park; site B = De Hoge Veluwe National Park. b Light intensity contrasts within Vaccinium vitis-idaea (site A), V. myrtillus (site C) and D. flexuosa (site $\mathrm{C}$ ): $\mathrm{S}+=$ shaded, $\mathrm{S}-=$ non-shaded. Data are means $\pm \mathrm{SE}(n=5)$ significantly when plants were shaded, whereas shading plus fertilisation resulted in the lowest amounts of total phenolics. As expected, the C:N ratios in the leaves decreased due to fertilisation and shading. In this experiment, fertilisation had a significant negative effect on the amount of mycorrhizal colonisation in the $C$. vulgaris roots. The mycorrhizal colonisation was positively related to the amount of inorganic nitrogen (linear regression, $\left.r^{2}=0.34, P=0.007\right)$, but negatively related to total biomass (linear regression, $r^{2}=0.23, P=0.03$ ) and root biomass (linear regression, $r^{2}=0.29, P=0.02$ ).

Field experiment

In the field experiment, the amount of total phenolics and $\mathrm{C}: \mathrm{N}$ ratio in ericaceous plants were negatively affected by both shading and fertilisation (Table 4). In contrast, the amount of condensed tannins was not affected. As expected, the fertilised plants had higher nitrogen concentrations than unfertilised plants. Mycorrhizal colonisation was only affected by shading. The shade treatment increased the amount of inorganic nitrogen and DON in the soil, but reduced the ratio DON:inorganic nitrogen. Mycorrhizal colonisation was not related to any of the measured plant or soil parameters. The amount of inorganic nitrogen was negatively correlated with the amount of total phenolics (linear regression, $r^{2}=0.29, P=0.02$ ) and condensed tannins in the plants (linear regression, $\left.r^{2}=0.20, P=0.06\right)$. 
Table 3 Results of the greenhouse experiment with Calluna vulgaris seedlings

\begin{tabular}{|c|c|c|c|c|c|c|c|}
\hline & $\mathrm{S}-\mathrm{F}-$ & $\mathrm{S}-\mathrm{F}+$ & $\mathrm{S}+\mathrm{F}-$ & $\mathrm{S}+\mathrm{F}+$ & $\mathrm{S}$ & $\mathrm{F}$ & $\mathrm{S} \times \mathrm{F}$ \\
\hline \multicolumn{8}{|l|}{ Plant } \\
\hline Total biomass (g dw) & $2.24(0.07)$ & $5.68(0.40)$ & $2.05(0.31)$ & $3.82(0.72)$ & $*$ & $* * *$ & NS \\
\hline Shoots (g dw) & $1.48(0.10)$ & $3.54(0.25)$ & $1.56(0.28)$ & $2.51(0.61)$ & NS & $* * *$ & NS \\
\hline Roots (g dw) & $0.76(0.18)$ & $1.71(0.30)$ & $0.33(0.08)$ & $0.42(0.03)$ & $* * *$ & $*$ & $*$ \\
\hline Shoot:root ratio & $2.31(0.47)$ & $2.47(0.61)$ & $5.06(0.44)$ & $5.99(1.30)$ & $* * *$ & NS & NS \\
\hline Flowers (g dw) & $0.25(0.04)$ & $0.99(0.11)$ & $0.21(0.04)$ & $0.34(0.05)$ & $* * *$ & $* * *$ & $* * *$ \\
\hline Total phenolics (mg tae/g dw) & $158(4)$ & $180(5)$ & $165(8)$ & $131(6)$ & $* *$ & NS & $* * *$ \\
\hline $\mathrm{C}(\%)$ & $47.6(0.4)$ & $48.4(0.2)$ & $49.1(1.2)$ & $48.1(0.4)$ & NS & NS & NS \\
\hline $\mathrm{N}(\%)$ & $1.2(0.1)$ & $1.3(0.0)$ & $1.6(0.3)$ & $1.8(0.1)$ & $* *$ & NS & NS \\
\hline $\mathrm{C}: \mathrm{N}$ ratio & $41.0(1.9)$ & $37.3(1.1)$ & $33.6(3.6)$ & $27.4(0.9)$ & $* * *$ & $*$ & NS \\
\hline Total N shoots (mg) & $26.0(1.4)$ & $74.0(5.2)$ & $31.0(4.3)$ & $66.0(1.1)$ & NS & $* * *$ & NS \\
\hline Mycorrhizal colonisation (\%) & $27.0(4.4)$ & $14.4(1.2)$ & $23.3(2.5)$ & $22.6(2.6)$ & NS & $*$ & NS \\
\hline \multicolumn{8}{|l|}{ Soil } \\
\hline Inorganic N (mg N/kg dw) & $3.66(0.16)$ & $0.52(0.09)$ & $2.72(0.48)$ & $1.61(0.27)$ & NS & $* * *$ & $* *$ \\
\hline $\mathrm{pH} \mathrm{KCl}$ & $7.1(0.0)$ & $7.2(0.0)$ & $7.2(0.1)$ & $7.2(0.0)$ & NS & $* *$ & NS \\
\hline
\end{tabular}

Average values $( \pm \mathrm{SE})$ are shown for the plant and soil characteristics. Significance levels for the main effects and the interaction between them are given

$* P<0.05 ; * * P<0.01 ; * * * P<0.001$

$\mathrm{NS}=$ non-significant

$\mathrm{S}+=$ with shade

$\mathrm{S}-=$ no shade

$\mathrm{F}+=$ with fertiliser

$\mathrm{F}-=$ no fertiliser

\section{Discussion}

Responses of mycorrhizal colonisation to $\mathrm{N}$ supply and light intensity

Our study shows that nitrogen supply negatively affects mycorrhizal colonisation of $C$. vulgaris roots under greenhouse conditions. This finding is in line with the results reported by Yesmin et al. (1996) and Mickel et al. (1991). It suggests that effects of nitrogen deposition are detrimental for the mycorrhizal colonisation of the dwarf shrub roots - and related to this-for the capacity of these plants to use the soluble organic nitrogen. However, in the field experiment, we found no detrimental effects of nutrient addition on colonisation rates. This is in agreement with the results of Lee et al. (1992), Caporn et al. (1995) and Johannson (2000), who also found no effects of nutrient addition on mycorrhizal colonisation in field experiments. Apparently, the soil litter layer in the field containing large amounts of organic acids stimulate more microorganisms than the sand medium used in the greenhouse experiment with alkaline $\mathrm{pH}$ (Tables 1 and 3). It seems that additional $\mathrm{NH}_{4}{ }^{+}-\mathrm{N}$ inputs become immobilised in the heath more layer (Adams 1986, Whitehead et al. 1997, Kristensen and Hendriksen 1998). Furthermore, the difference between the response to nutrient supply in terms of the amount of mycorrhizal colonisation of heather roots in the field and greenhouse experiments might be explained by the fact that only in the greenhouse was it possible to establish strong nitrogen-limited conditions.

In the Dutch heathlands, nitrogen deposition has increased soil nutrient supply significantly and heather plants are now less nitrogen-limited than several decades ago (Bobbink et al. 1998). The nitrogen concentrations in the plant can be used as estimators of the atmospheric nitrogen deposition (Hicks et al. 2000). In the control plots of our field experiment, the nitrogen concentration in the leaves of $C$. vulgaris was, on average $1.61 \%$, compared with 
Table 4 Results of the field experiment at De HogeVeluwe National Park with Calluna vulgaris plants

\begin{tabular}{|c|c|c|c|c|c|c|}
\hline & $S-F-$ & $S-F+$ & $\mathrm{S}+\mathrm{F}-$ & $\mathrm{S}+\mathrm{F}+$ & $S$ & $\mathrm{~F}$ \\
\hline \multicolumn{7}{|l|}{ Plant } \\
\hline Total phenolics (mg tae/ g dw) & 707 (86) & $462(56)$ & $443(51)$ & $383(52)$ & $*$ & $*$ \\
\hline Cond. tannins $\left(\mathrm{A}_{550} / 0.19 \mathrm{~g} \mathrm{dw}\right)$ & $0.042(0.006)$ & $0.021(0.007)$ & $0.021(0.008)$ & $0.016(0.008)$ & NS & NS \\
\hline$\% \mathrm{C}$ & $52.0(0.5)$ & $52.6(0.3)$ & $52.0(0.2)$ & $51.9(1.0)$ & NS & NS \\
\hline$\% \mathrm{~N}$ & $1.6(0.1)$ & $1.8(0.1)$ & $1.8(0.1)$ & $2,0(0.1)$ & NS & $*$ \\
\hline $\mathrm{C}: \mathrm{N}$ ratio & $32.5(1.1)$ & $28.9(1.1)$ & $29.0(0.9)$ & $26.3(1.4)$ & $*$ & * \\
\hline Mycorrhizal colonisation (\%) & $20.92(0.67)$ & $20.12(0.45)$ & $11.36(0.36)$ & $10.70(0.04)$ & $*$ & NS \\
\hline \multicolumn{7}{|l|}{ Soil } \\
\hline Inorganic N (mg N/ kg dw) & $5.78(1.10)$ & $8.25(1.23)$ & $13.46(1.18)$ & $14.35(1.61)$ & $* * *$ & NS \\
\hline DON (mg N/ kg dw) & $19.34(1.09)$ & $23.39(2.04)$ & $27.21(1.61)$ & $27.69(2.21)$ & $* *$ & NS \\
\hline DON: inorg. $\mathrm{N}$ ratio & $3.94(0.90)$ & $3.03(0.34)$ & $2.04(0.08)$ & $1.97(0.09)$ & $* *$ & NS \\
\hline $\mathrm{pH} \mathrm{KCl}$ & $2.8(0.0)$ & $2.8(0.0)$ & $2.8(0.0)$ & $2.8(0.0)$ & NS & NS \\
\hline $\mathrm{pH} \mathrm{H} \mathrm{H}_{2} \mathrm{O}$ & $3.8(0.0)$ & $3.8(0.1)$ & $3.8(0.1)$ & $3.9(0.1)$ & NS & NS \\
\hline
\end{tabular}

Average values $( \pm 1 \mathrm{SE})$ are shown for the plant and soil characteristics. Significance levels for the main effects between them are given

$* P<0.05 ; * * P<0.01 ; * * * P<0.001$

$\mathrm{NS}=$ non-significant

There were no significant interactions between the effects of the two treatments

$\mathrm{S}+=$ with shade

$\mathrm{S}-=$ no shade

$\mathrm{F}+=$ with fertiliser

$\mathrm{F}-=$ no fertiliser

$1.17 \%$ in the greenhouse (Tables 3 and 4 ). Therefore, it is not surprising that the long-term effects of nitrogen supply on mycorrhizal colonisation under our field conditions were less pronounced than the effects observed in the greenhouse. We conclude that the negative effects of increased atmospheric nitrogen on mycorrhizal colonisation of ericoid heathland plants still remain hypothetical. More experiments under field conditions are needed to investigate the effects of increased atmospheric nitrogen on the reduction of mycorrhizal colonisation and the possible consequences for organic nitrogen uptake.

In the field inventory, we found in general a positive correlation between the amount of mycorrhizal colonisation in ericaceous plants and the concentration of total phenolics in the leaves. In contrast, neither of the experiments with $C$. vulgaris showed such a relationship. Although Sokolovski et al. (2002) also showed an increased organic nitrogen uptake by $C$. vulgaris root cells colonised by a mycorrhizal symbiont, the actual importance of the role of mycorrhiza for amino acid uptake in the field is still being debated (Persson and Näsholm 2001).

Our finding that shading reduced the amount of mycorrhizal colonisation in ericaceous plants under field conditions is consistent with predictions of the CNB hypothesis and the protein competition model (Bryant et al. 1983, Jones and Hartley 1999). Simard et al. (2002) report that mycorrhizal fungi may receive carbon (e.g. sugars) amounting to $15-30 \%$ of the net photosynthate of their host plants. Also other studies (Bryant et al. 1983, Smith and Read 1997, Jones and Hartley 1999) have reported that shading reduced the amount of photosynthetic assimilates and therefore limited the amount of carbon translocated to the mycorrhizal symbiosis.

Responses of tannins to $\mathrm{N}$ supply and light intensity

Our results show that the CNB hypothesis can be very useful when predicting the amount of total phenolics in C. vulgaris under field conditions. The results from 
the Vaccinium plants in the field inventory and the results from the field experiment confirmed our hypothesis that shade negatively affects the foliar concentration of total phenolics-a result previously found by Iason and Hester (1993). The deviating results in the greenhouse experiment where we found an increase of phenolic concentrations in shaded plants can be caused by the lower intensity of the overall shade reduction compared to the field conditions by which the shaded plants showed less contrast with the control plants. This is also shown by the small differences between the total biomasses of the treatments. However, the direction of the responses in the shade, fertiliser and combined treatments is comparable between the field and the greenhouse experiment.

Our experiment is the first report that the addition of fertiliser results in lower concentrations of total phenolics in $C$. vulgaris under field conditions. The reason for the failure in previous field experiments with $C$. vulgaris to detect a significant fertiliser effect on the foliar content of total phenolics (Iason and Hester 1993, Iason et al. 1993, Hartley et al. 1995, Alonso et al. 2001) is probably that these experiments were too short (most lasted less than 1 year).

We found that the amount of condensed tannins was not significantly affected by the addition of fertiliser. This is in accordance with the results of Iason and Hester (1993) and Bradley et al. (2000). Shading also had no detectable effect on the tannin levels. Concentrations of tannins in $C$. vulgaris plants do not seem to vary strongly. The contrasting results of Hansen et al. (2006) in which concentrations of condensed tannins increased with $8-13 \%$ in ericaceous shrubs after shading and a combined treatment with fertiliser can be due to the cold subartic conditions, which could cause different translocation processes of carbon-based secondary compounds in the plant and in the studied 1-year old leaves.

We conclude from our field study that there is much natural variation in total phenolic and condensed tannin contents within and among ericaceous plants and that this depends strongly on site characteristics (light, soil nutrients) and plant species. The deciduous species, $V$. myrtillus seemed to have more plastic leaf characteristics than the evergreen species. The variation within and between the two grass species was remarkably smaller. The dominant grass species, which have higher growth rates than the dwarf shrubs, showed lower concentrations of secondary plant compounds. So, it is not surprising that there is a strong negative correlation between the foliar concentration of nitrogen and the concentrations of total phenolics and condensed tannins among plant species. The protein competition model (Jones and Hartley 1999) also suggests that the regulation of protein and phenolic synthesis are tightly linked due to the use of the same precursor phenylalanine. Therefore, plant cells do not appear to be capable of simultaneously synthesising proteins and phenolics at the same rate (Haukioja et al. 1998).

Consequences for the competition between dwarf shrubs and grasses

Berendse and Elberse (1990) hypothesized that ericaceous plants growing in nutrient-poor ecosystems have a competitive advantage over grass species because they are rich in carbon-based secondary compounds that prolong their life span and reduce nitrogen losses. We formulate the additional hypothesis that the symbiosis of ericaceous plants with their ericoid mycorrhizal fungi that degrade protein-phenolic complexes in the soil enables them to use organic nitrogen sources not available to other plants like grasses with their arbuscular mycorrhizal fungi (Berendse and Elberse 1990; Northup et al. 1995; Hättenschwiler and Vitousek 2000; Hodge et al. 2001; Aerts 2002).

Increased nitrogen deposition can seriously hamper the competitive advantage of ericaceous plants, not only by increasing the nitrogen availability in the soil, but also as this study and others have shown, by enhancing the nitrogen concentration in ericaceous litter (e.g. Hartley et al. 1995). This leads to the reduction of the carbon:nitrogen ratio in the litter, which accelerates its decomposition, and finally accelerates the mineralisation of the soil nitrogen (Berendse et al. 1994, Bret-Harte et al. 2004). When nutrient-poor soils become enriched with nitrogen, the grasses have a competitive advantage over ericaceous plants as they are able to benefit faster from the increased nitrogen supplies (Berendse et al. 1994). For example, the competition experiment of Berendse and Aerts (1984) showed that the dwarf shrub Erica tetralix was only able to outcompete Molinia cearulea at the non-fertilised, nutrient-poor sites, while Molinia replaced Erica after nutrient addition. 
Secondly, our study revealed that the levels of total phenolics in the ericaceous plants can decrease in response to nitrogen additions, thereby enhancing the degradation of the litter and accelerating $\mathrm{N}$ mineralisation (Schofield et al. 1998). Due to the reduced concentrations of phenolic compounds in the litter, the inorganic forms of soil nitrogen can increase relative to the organic forms (Northup et al. 1995, 1998). The field experiment with $C$. vulgaris showed that organic nitrogen was the most important labile nitrogen form, exceeding the amount of inorganic nitrogen by approximately 2-4 times (Table 4).

Under nitrogen-poor condition, the symbiosis of ericaceous plants with their mycorrhizal fungi, which are able to use complex organic nitrogen sources, supposedly gives them an advantage. So, when the organic nitrogen sources become relatively less important due to increased atmospheric nitrogen, the grasses-which can benefit more from the inorganic nitrogen sources than ericaceous plants-will outcompete the heathland shrubs (Berendse and Aerts 1984). Notwithstanding the fact that the grass, Deschampsia have been shown to be also able to use organic nitrogen (Näsholm et al. 1998; Falkengren-Grerup et al. 2000) and even can be colonized by ericoid endophytic fungi (Zijlstra et al. 2005), the highest $\mathrm{N}$ uptake rates are realised on ammonium and nitrate sources (Persson et al. 2003). Although the responses in our experiments were different, our data from the greenhouse experiment show that increased nitrogen addition can reduce mycorrhizal colonisation, which can result in less organic nitrogen being available to the ericaceous species (Sokolovski et al. 2002).

Finally, our data strengthen the idea of a positive feedback in the competition between ericaceous plants and grasses as a result of reduced light intensities, when nitrogen inputs increase. Shaded heathland plants seem to not only produce less phenolics and tannins and higher nitrogen concentrations in the leaves, but also tend to show reduced levels of mycorrhizal colonisation. In this way, shading reduces the competitive ability of heathland plants by directly reducing their nitrogen uptake capacity so that the expansion of the grasses at the cost of the dwarf shrubs will be strongly accelerated.

Acknowledgements We thank Bart Boers (De Hoge Veluwe National Park, Otterloo), Staatsbosbeheer (State Forest Service, Uchelen) and Dwingelderveld National Park for permission to collect the plant material, root and soil samples. We also thank Elena Mosca (University of Padua) and Pieter van 't Hof for measuring mycorrhizal colonisation. Joy Burrough advised on the English.

Open Access This article is distributed under the terms of the Creative Commons Attribution Noncommercial License which permits any noncommercial use, distribution, and reproduction in any medium, provided the original author(s) and source are credited.

\section{References}

Adams JA (1986) Nitrification and ammonification in acid forest litter and humus as affected by peptone and ammonium-N amendment. Soil Biol Biochem 18:45-51. doi:10.1016/0038-0717(86)90102-1

Aerts R (1993) Competition between dominant plant species in heathlands. In: Aerts RH, Heil GW (eds) Heathlands: patterns and processes in a changing environment. Kluwer Academic Publishers, Dordrecht, pp 51-84

Aerts R (2002) The role of various types of mycorrhizal fungi in nutrient cycling and plant competition. In: Van der Heijden MGA, Sanders I (eds) Mycorrhizal ecology, ecological studies, vol 157. Springer, New York, pp 117134

Alonso I, Hartley SE, Thurlow M (2001) Competition between heather and grasses on Scottisch moorlands: interacting effects of nutrient enrichment and grazing regime. J Veg Sci 12:249-260. doi:10.2307/3236609

Be'reau M, Barigah TS, Louisanna E (2000) Effects of endomycorrhizal development and light regimes on the growth of Dicorynia guianensis Amshoff seedlings. Ann For Sci 57:725-733. doi:10.1051/forest:2000153

Becker P (1983) Ectomycorrhizas on Shorea (Dipterocarpaceae) seedlings in a lowland Malaysian rainforest. Malay For 46:146-170

Bending GD, Read DJ (1997) Lignin and soluble phenolic degradation by ectomycorrhizal and ericoid mycorrhizal fungi. Mycol Res 101:1348-1354. doi:10.1017/S095375 6297004140

Berdowski JJM, Siepel H (1988) Vegetative regeneration of Calluna vulgaris at different ages and fertilizer levels. Biol Conserv 46:85-93. doi:10.1016/0006-3207(88) 90093-6

Berendse F, Aerts R (1984) Competition between Erica tetralix and Molinia caerulea as affected by the availability of nutrients. Acta Oecol Oecol Plant 19:3-14

Berendse F, Elberse WT (1990) Competition and nutrient availability in heathland and grassland ecosystems. In: Grace JB, Tilman D (eds) Perspectives on plant competition. Academic Press, London, pp 93-116

Berendse F, Schmidt M, De Visser W (1994) Experimental manipulation of succession in heathland ecosystems. Oecologia 100:38-44. doi:10.1007/BF00317128

Bobbink R, Heil GW (1993) Atmospheric deposition of sulphur and nitrogen in heathland ecosystems. In: Aerts R, Heil GW (eds) Heathland: Patterns and Processes in a 
Changing Environment, Geobotany, vol 20. Kluwer, Dordrecht, pp 25-50

Bobbink R, Hornung M, Roelofs JGM (1998) The effects of air-borne nitrogen pollutants on species diversity in natural and semi-natural European vegetation. $\mathrm{J}$ Ecol 86:717-738. doi:10.1046/j.1365-2745.1998.8650717.x

Bradley RL, Titus BD, Preston CP (2000) Changes to mineral $\mathrm{N}$ cycling and microbial communities in black spruce humus after additions of $\left(\mathrm{NH}_{4}\right)_{2} \mathrm{SO}_{4}$ and condensed tannins extracted from Kalmia angustifolia and balsam fir. Soil Biol Biochem 32:1227-1240. doi:10.1016/S00380717(00)00039-0

Brearly FQ, Scholes JD, Press MC, Palfner G (2007) How does light and phosphorus fertilisation affect the growth and ectomycorrhizal community of two contrasting dipterocarp species? Plant Ecol 192:237-249. doi:10.1007/ s11258-007-9325-6

Bret-Harte MS, Garcia EA, Sacre VM, Whorley JR, Wagner JL, Lippert SC, Chapin FSIII (2004) Plant and soil responses to neighbour removal and fertilization in Alaskan tussock tundra. J Ecol 92:635-647. doi:10.1111/j.0022-0477.2004. 00902.x

Bryant JP, Chapin FSIII, Klein DR (1983) Carbon/nutrient balance of boreal plants in relation to vertebrate herbivory. Oikos 40:357-368. doi:10.2307/3544308

Caporn SJM, Song W, Read DJ, Lee JA (1995) The effect of repeated nitrogen fertilization on mycorrhizal infection in heather. New Phytol 129:605-609. doi:10.1111/j.14698137.1995.tb03028.x

Carrol JA, Caporn SJ, Cawley L, Read DJ, Lee JA (1999) The effect of increased deposition of atmospheric nitrogen on Calluna vulgaris in upland Britain. New Phytol 141:423431. doi:10.1046/j.1469-8137.1999.00358.x

Chapin FSIII (1995) New cog in the nitrogen cycle. Nature 377:199-200. doi:10.1038/377199a0

Dehlin H, Nilsson M-C, Wardle DA, Shevtsova A (2004) Effects of shading and humus fertility on growth, competition and ectomycorrhizal colonization of boreal forest tree seedlings. Can J For Res 34:2573-2586. doi: 10.1139/x04-143

Duncan AJ, Hartley SE, Iason GR (1994) Fine-scale discrimination of forage quality by sheep offered a soyabean meal or barley supplement while grazing a nitrogen-fertilized heather (Calluna vulgaris) mosaic. J Agric Sci 123:363370

Falkengren-Grerup U, Månsson KF, Olsson MO (2000) Uptake capacity of amino acids by ten grasses and forbs in relation to soil acidity and nitrogen availability. Environ Exp Bot 44:207-219. doi:10.1016/S0098-8472(00)00068-X

Fierer N, Schimel JP, Cates RG, Zou J (2001) Influence of balsam poplar tannin fractions on carbon and nitrogen dynamics in Alaskan taiga floodplain soils. Soil Biol Biochem 33:1827-1839. doi:10.1016/S0038-0717(01) 00111-0

Gordon C, Woodin SJ, Alexander IJ, Mullins CE (1999) Effects of increased temperature, drought and nitrogen supply on two upland perennials of contrasting functional type: Calluna vulgaris and Pteridium aquilinum. New Phytol 142:243-258. doi:10.1046/j.1469-8137.1999. 00399.x
Handley WRC (1961) Further evidence for the importance of residual leaf protein complexes in litter decomposition and the supply of nitrogen for plant growth. Plant Soil 15:37-73. doi:10.1007/BF01421749

Hansen AJ, Jonasson S, Michelson A, Julkunen-Tiitto R (2006) Long-term experimental warming, shading and nutrient addition affect the concentration of phenolic compounds in arctic-alpine deciduous and evergreen dwarf shrubs. Oecol 147:1-11. doi:10.1007/s00442-005-0233-y

Harborne JB (1997) Role of phenolic secondary metabolites in plants and their degradation in nature. In: Cadish G, Giller KE (eds) Driven by nature, plant litter quality and decomposition. Cambridge University Press, Cambridge, pp 67-74

Hartley SE, Nelson K, Gorman M (1995) The effect of fertilizer and shading on plant chemical composition and palatability to Orkney voles, Microtus arvalis orcadensis. Oikos 72:79-87. doi:10.2307/3546041

Hartley SE, Iason GR, Duncan AJ, Hitchcock D (1997) Feeding behaviour of red deer (Cervus elaphus) offered Sitka spruce saplings (Picea sitchensis) grown under different light and nutrient regimes. Funct Ecol 11:349-357. doi:10.1046/j.1365-2435.1997.00094.x

Haslam E (1998) Practical polyphenolics, from structure to molecular recognition and physiological action. Cambridge University Press, London

Hättenschwiler S, Vitousek PM (2000) The role of polyphenols in terrestrial ecosystem nutrient cycling. Trends Ecol Evol 15:238-243. doi:10.1016/S0169-5347(00)01861-9

Haukioja E, Ossipov V, Koricheva J, Honkanen T, Larsson S, Lempa K (1998) Biosynthetic origin of carbon-based secondary compounds: cause of variable responses of woody plants to fertilization? Chemoecology 8:133-139. doi: $10.1007 / \mathrm{s} 000490050018$

Heil GW, Diemont WH (1983) Raised nutrient levels change heathland into grassland. Vegetatio 53:113-120. doi: 10.1007/BF00043031

Henriksson J, Haukioja E, Ossipov V, Ossipova S, Sillanpää S, Kapari L, Pihlaja K (2003) Effects of host shading on consumption and growth of the geometrid Epirrita autumnata: interactive roles of water, primary and secondary compounds. Oikos 103:3-16. doi:10.1034/j.1600-0706. 2003.12306.x

Hicks WK, Leith ID, Woodin SJ, Fowler D (2000) Can the foliar nitrogen concentration of upland vegetation be used for predicting atmospheric nitrogen deposition? Evidence from field surveys. Environ Pollut 107:367-376. doi: 10.1016/S0269-7491(99)00166-9

Hodge A, Campbell CD, Fitter AH (2001) An arbuscular mycorrhizal fungus accelerates decomposition and acquires nitrogen directly from organic material. Nature 413:297-299. doi:10.1038/35095041

Iason GR, Hester AJ (1993) The response of heather (Calluna vulgaris) to shade and nutrients-predictions of the carbon-nutrient balance hypothesis. J Ecol 81:75-80. doi: $10.2307 / 2261225$

Iason GR, Hartley SE, Duncan AJ (1993) Chemical composition of Calluna vulgaris (Ericaceae): do responses to fertilizer vary with phenological stage? Biochem Syst Ecol 21:315-321. doi:10.1016/0305-1978(93)90023-K 
Iason GR, Duncan AJ, Hartley SE, Staines BW (1996) Feeding behaviour of red deer (Cervus elaphus) on Sitka spruce (Picea sitchensis): the role of carbon-nutrient balance. For Ecol Manage 88:121-129. doi:10.1016/S0378-1127(96) 03817-0

Ingleby K, Munro RC, Noor M (1998) Ectomycorrhizal populations and growth of Shorea parvifolia (Dipterocarpaceae) seedlings regenerating under three different forest canopies following logging. For Ecol Manage 111:171-179. doi: 10.1016/S0378-1127(98)00324-7

Johannson M (2000) The influence of ammonium nitrate on the root growth and ericoid mycorrhizal colonization of Calluna vulgaris (L.) Hull from a Danish heathland. Oecol 123:418-424. doi:10.1007/s004420051029

Jones CG, Hartley SE (1999) A protein competition model of phenolic allocation. Oikos 86:27-44. doi:10.2307/3546567

Kerslake JE, Woodin SE, Hartley SE (1998) Effects of carbon dioxide and nitrogen enrichment on a plant-insect interaction: the quality of Calluna vulgaris as a host for Operophtera brumata. New Phytol 140:43-53. doi: 10.1046/j.1469-8137.1998.00244.x

Kristensen HL, Hendriksen K (1998) Soil nitrogen transformations along a succesional gradient from Calluna heathland to Quercus forest at intermediate atmospheric nitrogen deposition. Appl Soil Ecol 8:95-109. doi: 10.1016/S0929-1393(97)00062-0

Lee JA, Caporn SJM, Read DJ (1992) Effects of increasing nitrogen deposition and acidification on heathlands. In: Schneider T (ed) Acidification research, evaluation and policy applications. Elsevier, Amsterdam, pp 97-106

Mallik AU (1996) Effect of NPK fertilizations on Kalmia angustifolia: implications for forest disturbance and conifer regeneration. For Ecol Manage 81:135-141. doi:10.1016/ 0378-1127(95)03659-8

Mickel S, Brunschön S, Fangmeier A (1991) Effects of nitrogen-nutrition on growth and competition of Calluna vulgaris (L.) Hull and Deschampsia flexuosa (L.). Trin Angew Bot 65:359-372

Näsholm T, Ekblad A, Nordin A, Giesier R, Högberg M, Högberg P (1998) Boreal forest plants take up organic nitrogen. Nature 392:914-916. doi:10.1038/31921

Nordin A, Näsholm T, Ericson L (1998) Effects of simulated N deposition on understorey vegetation of a boreal coniferous forest. Funct Ecol 12:691-699. doi:10.1046/j.13652435.1998.00240.x

Northup RR, Yu Z, Dahlgren RA, Vogt KA (1995) Polyphenol control of nitrogen release from pine litter. Nature 377:227-229. doi:10.1038/377227a0

Northup RR, Dahlgren RA, McColl JG (1998) Polyphenols as regulators of plant-litter-soil interactions in northern California's pygmy forest: a positive feedback? Biogeochemistry 42:189-220. doi:10.1023/A:1005991908504

Olsrud M, Melilo JM, Christensen TR, Michelsen A, Wallander H, Olsson PA (2004) Response of ericoid mycorrhizal colonization and functioning to global change factors. New Phytol 162:459-469. doi:10.1111/ j.1469-8137.2004.01049.x

Olsrud M, Michelsen A, Wallander H (2007) Ergosterol content in ericaceous hair roots correlates with dark septate endophytes but not with ericoid mycorrhizal colonization.
Soil Biol Biochem 39:1218-1221. doi:10.1016/j.soilbio. 2006.11.018

Persson J, Näsholm T (2001) Amino acid uptake: a widespread ability among boreal forest plants. Ecol Lett 4:434-438. doi:10.1046/j.1461-0248.2001.00260.x

Persson J, Högberg P, Ekblad A, Högberg MN, Nordgren A, Näsholm T (2003) Nitrogen acquisition from inorganic and organic sources by boreal forest plants in the field. Ecosyst Ecol 137:252-257

Porter LJ, Hrstich LN, Chan BC (1986) The conversion of procyanidins and prodelphinidins to cyanidin and delphinidin. Phytochemistry 25:223-230. doi:10.1016/S00319422(00)94533-3

Power SA, Ashmore MR, Cousins DA, Sheppard LJ (1998) Effects of nitrogen addition on the stress sensitivity of Calluna vulgaris. New Phytol 138:663-673. doi: 10.1046/j.1469-8137.1998.00160.x

Prajadinata S, Santoso E (1993) The influence of light intensity on mycorrhizal development on Shorea spp. seedlings. In: Soerianegara I, Supriyanto (eds) Proceedings of second Asian conference on mycorrhiza. BIOTROP Special Publication 42, Bogor, pp 101-106

Prescott CE, Coward LP, Weetman GF, Gessel SP (1993) Effects of repeated nitrogen fertilization on the ericaceous shrub, salal (Gaulteria shallon), in two coastal Douglas-fir forests. For Ecol Manage 61:45-60. doi:10.1016/03781127(93)90189-T

Read DJ (1996) The structure and function of the ericoid mycorrhizal root. Ann Bot (Lond) 77:365-374. doi: 10.1006/anbo.1996.0044

Read DJ, Leake JR, Perez-Moreno J (2004) Mycorrhizal fungi as drivers of ecosystem processes in heathland and boreal forest biomes. Can J Bot 82:1243-1263. doi: 10.1139/b04-123

Ruohomäki K, Chapin FSIII, Haukioja E, Neuvonen S, Suomela J (1996) Delayed inducible resistance in mountain birch in response to fertilization and shade. Ecology 77:2302-2311. doi:10.2307/2265732

Schimel JP, Van Cleve K, Cates RG, Clausen TP, Reichardt PB (1996) Effects of balsam poplar (Populus balsamifera) tannins and low molecular weight phenolics on microbial activity in taiga floodplain soil: implications for changes in $\mathrm{N}$ cycling during succession. Can J Bot 74:84-90. doi: 10.1139/b96-012

Schimel JP, Cates RG, Ruess R (1998) The role of balsam poplar secondary chemicals in controlling soil nutrient dynamics through succession in the Alaskan taiga. Biogeochemistry 42:221-234. doi:10.1023/A:1005911118982

Schofield JA, Hagermann A, Harold A (1998) Loss of tannins and other phenolics from willow leaf litter. J Chem Ecol 24:1409-1421. doi:10.1023/A:1021287018787

Simard SW, Jones MD, Durall DM (2002) Carbon and nutrient fluxes within and between mycorrhizal plants. In: Van der Heijden MGA, Sanders I (eds) Mycorrhizal ecology, ecological studies, vol 157. Springer, New York, pp 33-74

Smith SE, Read DJ (1997) Mycorrhizal symbiosis, 2nd edn. Academic Press, London

Sokolovski SG, Meharg AA, Maathuis FJM (2002) Calluna vulgaris root cells show increased capacity for amino acid uptake when colonized with the mycorrhizal fungus 
Hymenoscyphus ericae. New Phytol 155:525-530. doi: 10.1046/j.1469-8137.2002.00485.x

Waterman PG, Mole S (1994) Analysis of phenolic plant metabolites. Blackwell Scientific Publications, Oxford

Whitehead SJ, Caporn SJM, Press MC (1997) Effects of elevated $\mathrm{CO}_{2}$, nitrogen and phosphorus on the growth and photosynthesis of two upland perennials: Calluna vulgaris and Pteridium aquilinum. New Phytol 135:201-211. doi: 10.1046/j.1469-8137.1997.00651.x

Yesmin L, Gammack SM, Cresser MS (1996) Effects of atmospheric deposition on ericoid mycorrhizal infection of Calluna vulgaris growing in peat soils. Appl Soil Ecol 4:49-60. doi:10.1016/0929-1393(96)00099-6

Yu Z, Northup RR, Dahlgren RA (1993) Determination of dissolved organic nitrogen using persulfate oxidation and conductimetric quantification of nitrate-nitrogen. Commun Soil Sci Plant Anal 25:3161-3169

Zijlstra JD, Van't Hof P, Baar J, Verkley GJM, Summerbell RC, Paradi I, Braakhekke WG, Berendse F (2005) Diversity of symbiotic root endophytes of the Helotiales in ericaceous plants and the grass, Deschampsia flexuosa. Stud Mycol 53:147-162 